\title{
Assessment of Undiscovered Continuous Oil and Gas Resources of Upper Cretaceous Shales in the Songliao Basin of China, 2017
}

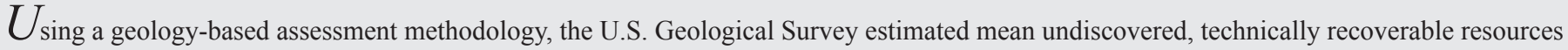
of 3.3 billion barrels of oil and 887 billion cubic feet of gas in shale reservoirs of the Upper Cretaceous Qingshankou and Nenjiang Formations in the Songliao Basin of northeastern China.

\section{Introduction}

The U.S. Geological Survey (USGS) quantitatively assessed the potential for continuous (unconventional) oil resources within organic-rich lacustrine shale of the Upper Cretaceous Qingshankou and Nenjiang Formations of the Songliao Basin. The Songliao Basin is the most productive oil-bearing nonmarine basin in China, mainly from the super-giant, conventional Daqing Oil Field (fig. 1). This field, discovered in 1959, produces oil from high-quality sandstone reservoirs in large anticlinal traps, sourced by adjacent lacustrine shale of the Qingshankou Formation (Lee, 1986; Li, 1995). Daqing Oil Field has produced over 12 billion barrels of oil, but production has declined in recent years. In light of this decline in conventional oil production, Cao and others (2017) and Liu and others (2017) analyzed the shale-oil potential of the Qingshankou. These authors noted that operators have completed preliminary exploration and tests, but there has been no reported shale-oil production in the Songliao Basin.

\section{Geologic Background}

The Qingshankou and Nenjiang Formations were deposited during a postrift sag basin phase characterized by strong subsidence that followed an Early Cretaceous rift phase in this continental retro-arc basin (Feng and others, 2010; Wang and others, 2016). The Qingshankou was deposited from 92.0 to 86.2 mega-annum (Ma) (Wang and others, 2016). Its organic-rich first (lowest) member is 60-135 meters (m) thick, covering an area of 87,000 square kilometers $\left(\mathrm{km}^{2}\right)$ (representing the maximum extent of the Upper Cretaceous lacustrine system), and present total organic carbon (TOC) content is typically 3-4 weight percent up to a maximum of 7.5 weight percent (Feng and others, 2010). Liu and others (2017) indicate several areas near the basin center where TOC exceeds 5 weight percent. The Nenjiang was deposited from 84.5 to $79.1 \mathrm{Ma}$ (Wang and others, 2016). Its organic-rich first and second members have a composite thickness of 200-400 m, cover an area of $20,000 \mathrm{~km}^{2}$, and contain TOC values of 1-3 weight percent (Feng and others, 2010). The Qingshankou and Nenjiang both contain Type I kerogen and are mainly within the oil window with vitrinite reflectance values in the center of the Songliao Basin exceeding 1.1 percent for the Qingshankou, decreasing below 0.5 percent near the basin margins (Feng and others, 2010; Liu and others, 2017). The depth to the Qingshankou source-rock interval exceeds 1 kilometer over a large area of the basin, with a maximum depth of about $2,650 \mathrm{~m}$, whereas the Nenjiang source rocks are 0-1,900 m deep (Li, 1995; Pan and others, 2010). The brittle mineral content of the Qingshankou exceeds 40 percent (relative mineral abundance) (Cao and others, 2017). Its clay content averages 55 percent (Liu and others, 2017), much higher than producing shale-oil reservoirs in the United States, raising concerns that it might not be amenable to effective hydraulic fracturing.

\section{Assessment Units}

Within the Upper Cretaceous Total Petroleum System, we defined two assessment units (AUs): the Qingshankou Formation Shale Oil AU and the Nenjiang Formation Shale Oil AU (fig. 1). Burial history modeling suggests that these units were buried sufficiently by Late Cretaceous sediments to generate oil beginning in the latest Cretaceous (Liu and others, 2017). The Qingshankou, being several hundred meters deeper than

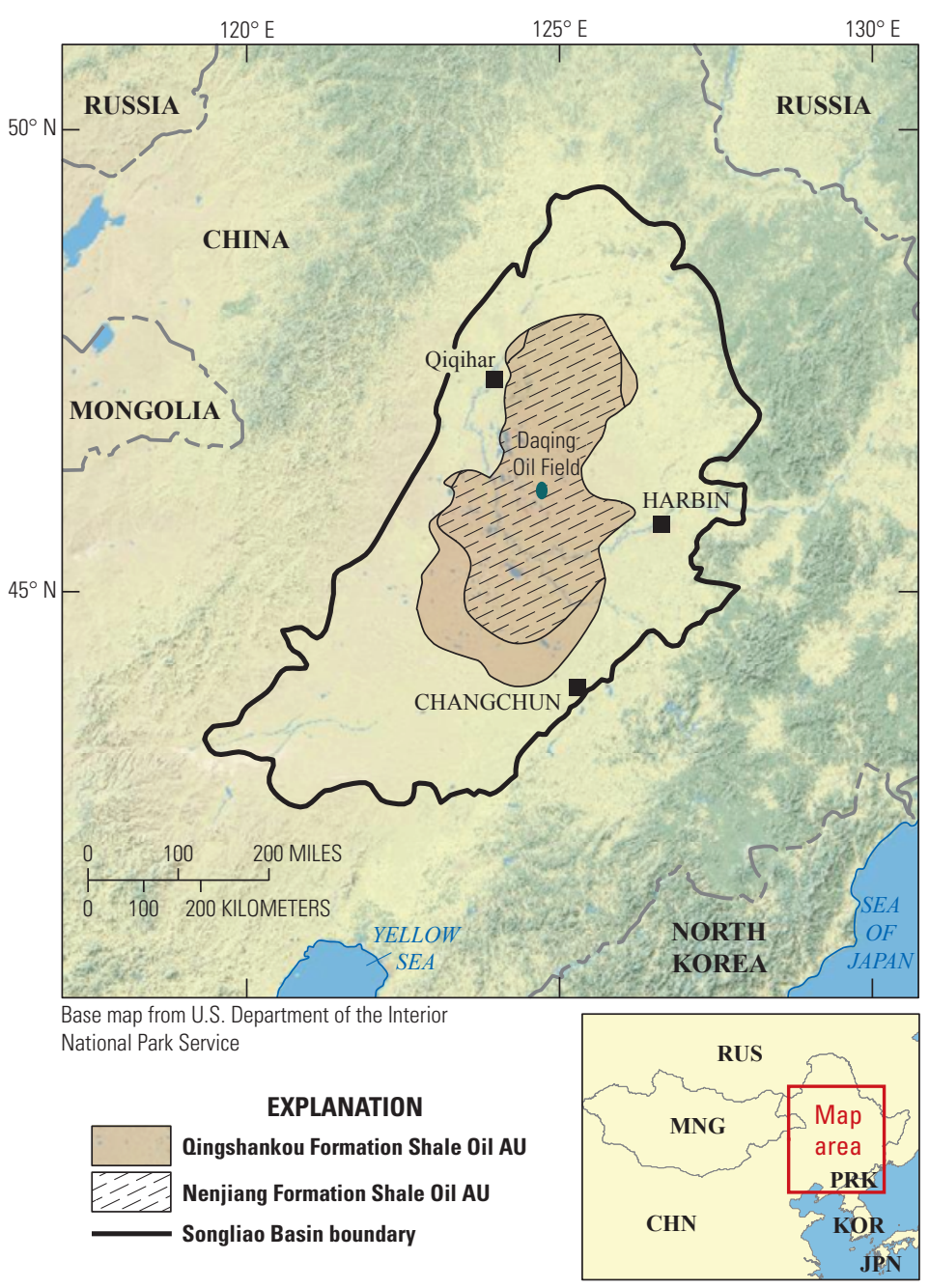

Figure 1. Map showing the location of the Songliao Basin and the Oingshankou Formation Shale Oil and Nenjiang Formation Shale Oil Assessment Units (AUs). 
the Nenjiang, has greater thermal maturity, but neither was buried deeply enough to become overmature. The thermal and burial conditions in the Songliao Basin were nearly optimal for oil generation. The Qingshankou Formation Shale Oil AU corresponds to areas where the thermal maturity of the Qingshankou has achieved vitrinite reflectance above 0.6 percent, according to Liu and others (2017). The areal extent of the Nenjiang
Formation Shale Oil AU is patterned after the Qingshankou Formation Shale Oil AU, truncated to exclude areas where the thickness of the Nenjiang is less than $100 \mathrm{~m}$ based on Feng and others (2010).

Continuous oil and gas accumulations in the United States were used as analogs in this assessment. Table 1 lists the principal input data used for the assessment.

Table 1. Key input data for two continuous assessment units in the Songliao Basin, China.

[AU, assessment unit; \%, percent; EUR, estimated ultimate recovery per well; MMBO, million barrels of oil. Well-drainage area, success ratio, and EUR are from U.S. shale-oil analogs. The average EUR input is the minimum, median, maximum, and calculated mean. Shading indicates not applicable]

\begin{tabular}{|l|c|c|c|c|c|c|c|c|}
\hline \multirow{2}{*}{$\begin{array}{c}\text { Assessment input data- } \\
\text { Continuous AUs }\end{array}$} & \multicolumn{3}{c|}{ Oingshankou Formation Shale Oil AU } & \multicolumn{4}{c|}{ Nenjiang Formation Shale Oil AU } \\
\cline { 2 - 9 } & Minimum & Mode & Maximum & $\begin{array}{c}\text { Calculated } \\
\text { mean }\end{array}$ & Minimum & $\begin{array}{c}\text { Mode } \\
\text { Maximum } \\
\text { Calculated } \\
\text { mean }\end{array}$ \\
\hline Potential production area of AU (acres) & 2,000 & $7,000,000$ & $16,300,000$ & $7,767,333$ & 2,000 & $4,000,000$ & $10,000,000$ & $4,667,333$ \\
\hline Average drainage area of well (acres) & 40 & 80 & 120 & 80 & 40 & 80 & 120 & 80 \\
\hline Success ratio (\%) & 10 & 50 & 90 & 50 & 10 & 40 & 90 & 46.7 \\
\hline Average EUR (MMBO) & 0.02 & 0.04 & 0.1 & 0.043 & 0.02 & 0.04 & 0.1 & 0.043 \\
\hline AU probability & 1.0 & & & & 1.0 & & \\
\hline
\end{tabular}

\section{Undiscovered Resources Summary}

The USGS quantitatively assessed the Qingshankou Formation Shale Oil AU and the Nenjiang Formation Shale Oil AU within the Upper Cretaceous Total Petroleum System in the Songliao Basin, northeast China (table 2). The mean total for continuous oil resources is 3,323 million barrels of oil (MMBO), or 3.3 billion barrels of oil, with an F95-F5 range from 720 to 7,469 MMBO. The mean total for continuous gas resources is 887 billion cubic feet (BCFG) with an F95-F5 range from 164 to 2,170 BCFG. The mean total for natural gas liquids is 22 million barrels of natural gas liquids (MMBNGL) with an F95-F5 range from 3 to 57 MMBNGL. These estimates are for undiscovered, technically recoverable resources of oil, gas, and natural gas liquids and do not reflect economically recoverable resources.

Table 2. Results for two continuous assessment units in the Songliao Basin, China.

[MMBO, million barrels of oil; BCFG, billion cubic feet of gas; NGL, natural gas liquids; MMBNGL, million barrels of natural gas liquids. Results shown are fully risked estimates. For gas accumulations, all liquids are included in the NGL category. F95 represents a 95-percent chance of at least the amount tabulated; other fractiles are defined similarly. Fractiles are additive under the assumption of perfect positive correlation. Shading indicates not applicable]

\begin{tabular}{|c|c|c|c|c|c|c|c|c|c|c|c|c|c|c|}
\hline \multirow{3}{*}{$\begin{array}{l}\text { Total petroleum system and } \\
\text { assessment units (AUs) }\end{array}$} & \multirow{3}{*}{$\begin{array}{c}\text { AU } \\
\text { prob- } \\
\text { ability }\end{array}$} & \multirow{3}{*}{$\begin{array}{l}\text { Accu- } \\
\text { mulation } \\
\text { type }\end{array}$} & \multicolumn{12}{|c|}{ Total undiscovered resources } \\
\hline & & & \multicolumn{4}{|c|}{ Oil (MMBO) } & \multicolumn{4}{|c|}{ Gas (BCFG) } & \multicolumn{4}{|c|}{ NGL (MMBNGL) } \\
\hline & & & F95 & F50 & F5 & Mean & F95 & $\mathrm{F} 50$ & F5 & Mean & F95 & F50 & F5 & Mean \\
\hline \multicolumn{15}{|c|}{ Upper Cretaceous Total Petroleum System } \\
\hline Qingshankou Formation Shale Oil AU & 1.0 & Oil & 470 & 1,853 & 4,734 & 2,131 & 107 & 464 & 1,380 & 569 & 2 & 11 & 36 & 14 \\
\hline Nenjiang Formation Shale Oil AU & 1.0 & Oil & 250 & 1,018 & 2,735 & 1,192 & 57 & 254 & 790 & 318 & 1 & 6 & 21 & 8 \\
\hline Total undiscovered continuous resources & & & 720 & 2,871 & 7,469 & 3,323 & 164 & 718 & 2,170 & 887 & 3 & 17 & 57 & 22 \\
\hline
\end{tabular}

\section{References Cited}

Cao H.R., Zou Y.-R., Lei Y., Xi D., Wan X.Q., and Peng P.A., 2017, Shale oil assessment for the Songliao Basin, northeastern China, using oil generation-sorption method: Energy Fuels, v. 31, p. 4826-4842. [Also available at https://doi.org/10.1021/acs.energyfuels.7b00098.]

Feng Z.Q., Jia C.Z., Xie X.N., Zhang S., Feng Z.H., and Cross, T.A., 2010, Tectonostratigraphic units and stratigraphic sequences of the nonmarine Songliao basin, northeast China: Basin Research, v. 22, no. 1, p. 79-95. [Also available at https://doi.org/10.1111/ j.1365-2117.2009.00445.x.]

Lee K.Y., 1986, Petroleum geology of the Songliao basin, Northeast China: U.S. Geological Survey Open-File Report 86-502, 19 p.

Li D.S., 1995, Hydrocarbon habitat in the Songliao Rift Basin, China, in Lambiase, J.J., ed., 1995, Hydrocarbon habitat in rift basins: Bath, United Kingdom, The Geological Society, London, Special Publication No. 80, p. 317-329.
Liu C.L., Wang Z.L., Guo Z.Q., Hong W.Y., Dun C., Zhang X., Li B., and Wu L.Q., 2017, Enrichment and distribution of shale oil in the Cretaceous Qingshankou Formation, Songliao Basin, northeast China: Marine and Petroleum Geology, v. 86, p. 751-770. [Also available at https://doi.org/10.1016/j.marpetgeo.2017.06.034.]

Pan S.X., Wang T.Q., Wei P.S., Wang J.G., Liu C.Y., and Liang S.J., 2010, Accumulation and exploration prospects of shale oil and gas in Songliao Basin, eastern China: American Association of Petroleum Geologists, Search and Discovery Article No. 10272, December 29, 2010, 8 p., accessed August 21, 2017, at http://www.searchanddiscovery.com/documents/2010/10272pan/.

Wang P.-J., Mattern, F., Didenko, N.A., Zhu D.-F., Singer, B., and Sun X.-M., 2016, Tectonics and cycle system of the Cretaceous Songliao Basin-An inverted active continental margin basin: Earth-Science Reviews, v. 159, p. 82-102. [Also available at https://doi.org/10.1016/j.earscirev.2016.05.004.]

Banner satellite image from Google, 2018

\section{Songliao Basin Assessment Team}

Christopher J. Potter, Christopher J. Schenk, Janet K. Pitman, Timothy R. Klett, Marilyn E. Tennyson, Stephanie B. Gaswirth, Heidi M. Leathers-Miller, Thomas M. Finn, Michael E. Brownfield, Tracey J. Mercier, Kristen R. Marra, Cheryl A. Woodall

\section{For More Information}

Assessment results are also available at the USGS Energy Resources Program website at https://energy.usgs.gov. 